\title{
경기, 금리, 주택가격
}

\section{김남현* 장한익**}

본 연구에서는 2010년 2월부터 2019년 5월까지의 자료를 사용하여 경기와 금리의 변화가 주택가격 또는 서울과 타 지역 간 주택가격 격차에 미치는 영향을 VAR 모형 과 Jorda(2005)의 국소투영모형을 이용하여 분석하였다. 실증분석결과를 살펴보면 서울 주택매매가격지수의 경우 선행지수의 상승충격에 대해 주택가격도 상승하는 것 으로 나타나며 콜금리의 상승충격에 주택가격은 하락하는 반응을 보인다. 따라서 선 행지수의 상승충격과 콜금리의 하락충격이 동시에 발생하는 경우 서울 주택가격은 가 장 크게 상승한다. 서울을 제외한 지방, 6 개 광역시, 9 개 도의 경우에는 선행지수의 충격에 대한 주택가격의 반응은 서울과 동일한 방향으로 나타나지만 콜금리의 상승충 격에 서울의 경우와 반대로 주택가격은 상승하는 반응을 보인다. 다음으로 서울을 중 심으로 지방, 6 개 광역시, 9 개 도의 주택매매가격지수 간 격차는 선행지수의 상승충 격, 콜금리의 상승충격이 발생하면 증가한다. 따라서 통화정책의 실행으로 예상되는 주택시장 전망은 현재 경기에 따라 상반된 결과로 실현될 수 있기 때문에 금리의 인 상 또는 인하에 따른 주택가격 변화를 예측하기 위해서는 현재의 경제상황도 충분히 고려되어야 한다.

핵심어 금리, 주택가격, 경기, 국소투영모형, 충격반응함수

* 예금보험공사 예금보험연구센터 부연구위원, 경제학 박사, kimnh0335@gmail.com, 제1저자

** 한국주택금융공사 주택금융연구원 부연구위원, 경제학 박사, hijang@hf.go.kr, 교신저자

※ 본고의 내용은 필자의 개인 의견으로 한국주택금융공사의 공식적인 견해와 다를 수 있습니다. 


\section{I . 서론}

미 연준은 2019년 7월과 9월에 각각 $0.25 \%$ 금리인하를 단행하였다. 하지만 트럼프 대통령 은 현재의 미국 금리수준이 높으며 추가적인 인하가 필요하다고 지속적으로 요구하고 있다. 이 는 미국의 경기회복을 부동산 정책으로 타개하겠다고 강조해 온 트럼프 대통령의 경제정책운용 에 걸림돌로 작용하는 것으로 판단되었기 때문이다. 반면 한국정부는 부동산 안정화 대책에 대 한 정책효과를 가시적으로 발현하기 위해 금리인상이 필요하다고 주장하였으나 미·중 무역전 쟁, 일본의 수출규제, 노딜 브렉시트, 이란 석유 제재 등에 따른 대외적 불확실성이 확대되면서 현실적으로 한국은행은 금리인하를 단행하였으며 장기간 금리인하 기조를 유지할 것으로 보고 있다. 이처럼 미국과 한국의 주택시장에 대한 정책목표는 다르지만 정책금리 조정을 통해 주택 가격을 조정하고자 하는 목적은 동일하다고 볼 수 있다.

이론적으로 금리와 주택가격은 음(-)의 관계를 갖는 것으로 보고 있다. 하지만 현실에서는 금 리와 주택가격 간의 관계를 일방적으로 정의하는 것은 다소 무리가 있다. 우선, Taylor(2007) 는 2002년 이후 미국 통화당국이 지나치게 확장적인 통화정책, 즉 지나치게 낮은 이자율정책 을 시행하여 주택가격이 급등하였고 주택가격의 상승이 반전되자 서브프라임 모기지사태가 발 생했다고 지적함으로써 통화정책과 주택시장 사이의 밀접한 관련성을 강조하였다. 하지만 미 연준 전 의장 Bernanke(2013)는 다양한 사례를 바탕으로 주택시장의 과열과 침체가 통화정책 과 밀접한 연관성이 없다고 지적하였다. 우선, 영국과 미국의 주택가격 과열 정도는 비슷하였으 나 영국의 통화정책은 미국에 비해 훨씬 더 긴축적이었음을 지적하였다. 둘째, 독일과 스페인은 동일한 유로화를 쓰고 유럽중앙은행(ECB)의 동일한 통화정책이 적용되지만 글로벌 금융위기 기간 독일의 주택가격은 큰 변화가 없는 반면 스페인은 주택가격의 급등이 발생하였음을 지적 하였다. 마지막으로 미국은 2004년 긴축적 통화정책을 실시하였지만 주택가격이 급격히 증가 하였으며, 이는 통화정책과 주택가격 간의 이론적 관계가 적용되지 않았다는 증거이기 때문에 Bernanke(2013)는 경기상승에 따른 심리적 낙관론이 주택가격을 상승시킨 주요 요인으로 판 단하였다.

우리나라도 박송춘(2009)은 통화정책과 주택가격 간의 음(-)의 관계성이 존재한다고 주장하 였지만 손종칠(2010)은 통화정책과 주택가격 간의 관계가 명확하지 않음을 지적하면서 국내의 분석결과에서도 상반된 실증분석 결과가 발표되면서 일관된 관계성을 보여주지 못하고 있다. 또한 국내의 경우 2008년 글로벌 금융위기 이후 경기가 나빠질 때 주택가격이 오르고 경기가 
회복되면서 오히려 주택시장이 침체되는 모습을 보이기도 한다. 이와 함께 장한익(2019)가 지 역별 주택가격 변화가 항상 동일한 방향성을 갖는 것은 아니라고 지적하였기 때문에 동일한 거 시경제 또는 금리의 변화가 지역별 주택가격 변화에 미치는 영향이 다르게 나타날 수 있는 요인 이 존재한다.

이와 같이 국내의 경우 소규모 개방경제인 특성을 감안하면 국내 주택경기의 현황과 상관없 이 해외요인에 의해 거시경제 또는 금리 변수가 일부 조정되어 일시적으로 실제 국내 주택시장 현황과 차이를 보이는 결과를 유도할 수 있음을 고려해야 한다. 또한 지역별 주택가격 간 동조 화 변화에 따라 지역별 주택가격에 대한 거시경제 및 금리의 영향력이 달라질 수 있음을 추가적 으로 고려할 필요가 있다. 따라서 본 연구에서는 VAR모형 외에 Jorda(2005)의 국소투영기법 (local projections technique)을 사용하여 경기와 금리의 변화가 주택가격 또는 서울과 타 지역 간 주택가격 격차에 미치는 영향을 동태적으로 분석하였다.

본 연구의 주요 실증분석결과를 요약하면, 서울 주택매매가격지수의 경우 선행지수의 상승 (하락)충격에 대해 주택가격도 상승(하락)하는 것으로 나타나며 콜금리의 상승(하락)충격에 주 택가격은 하락(상승)하는 반응을 보인다. 반면 서울을 제외한 지방, 6개 광역시, 9개 도의 경우 에는 선행지수의 충격에는 서울의 경우와 동일한 방향으로 나타나나 콜금리의 충격에는 반응의 방향이 같지 않다.

본 연구는 다음과 같은 내용을 다루고 있다. 제 피절에서는 경기, 금리, 주택가격 등의 관계를 분석하고 있는 기존 연구들을 살펴본다. 제피절에서는 본 연구에서 사용된 변수들의 전체 분석 기간 동안 추이 및 통계적 특성을 살펴보고 단위근 및 공적분 검정을 실시한다. 제IV절에서는 $\operatorname{Jorda}(2005)$ 의 국소투영기법을 중심으로 본 연구에서 사용되는 추정방법들을 설명한다. 제V 절에서는 VAR 모형과 국소투영모형을 이용해 경기와 금리의 변화가 주택가격 및 서울과 타 지 역 간 주택가격 격차에 미치는 영향을 비교·분석한다. 제VI절에서는 본 연구내용을 요약하고 결론을 맺는다.

\section{II . 선행연구}

금리와 주택가격 간 관계에 대한 연구의 결과들은 일반적으로 알려진 것처럼 음(-)의 관계를 보이는 경우가 많다. 하지만 글로벌 금융위기 이후 경제구조가 복잡해지면서 단순히 이들이 음 
(-)의 관계를 가진다고 가정하는 것은 무리가 있다. 이에 대해 김남현·장한익(2018)에서는 TVC-VAR(4) 모형을 이용하여 금리와 주택가격 간의 관계가 단순히 음(-)의 관계라기보다는 금리 상승에 대한 기대에 따라 달라질 수 있다고 주장하고 있다. 특히, 가능한 요인들 중 LTV 나 DTI 등 부동산 정책의 영향이 다소 줄어드는 반면에 기대인플레이션이나 장·단기 금리, 국내 외 정책금리 등에 대한 영향력이 크다고 밝히고 있다. 또한 황영진(2015)은 주택가격이 상승하 는 시기에는 실물경제와 탈동조화 되어 있음을 분석했다. 본 연구에서는 이들의 연구와는 관점 을 달리하여 금리 변화의 요인이 될 수 있는 경기수준을 추가로 반영한 후 경기상황의 변화와 금리 변화가 동시에 나타나는 경우 주택가격에 미치는 영향을 분석하고자 한다. 또한 투기수요 가 많은 서울 주택가격과 지방 주택가격 간 차이에 미치는 영향과 그 원인에 대해 살펴본다. 손 종칠(2010)도 금융위기 이전에 정책금리와 주택가격 간 상관관계를 중심으로 분석하였다. 또 한 전해정(2014)은 금융위기를 기점으로 CD금리가 주택가격에 미치는 영향이 음(-)에서 양(+) 으로 변화했으며, 그 원인으로 금융위기 이후 주택가격 하락과 금리 하락세가 맞물려 나타난 현 상을 들었다. 이근영·김남현(2016)은 금리와 주택가격을 상승 및 하락기로 분리하여 금리 상승 과 주택가격 하락 시 금리 인상이 주택가격을 가장 크게 낮춘다는 것을 보여주었다.

해외연구로 Himmelberg et al.(2005)와 Cambell, Gallin and, Martin(2009)는 주택가 격의 변동에 금리가 유의한 영향을 미치고 있다고 분석하고 있다. 또한 Maurin et al.(2012)는 2국면 마코프-스위칭 모형을 통해 프랑스에서 금리가 주택가격에 미치는 영향이 일정하지 않 음을 보였다. 유사한 연구로 Nneji, Brooks and, Ward(2013)은 3국면 마코프-스위칭 모형을 통해 금리 인하가 주택가격의 국면전환에 중요한 요인임을 밝혔다.

\section{III. 자료의 특성}

본 연구에서는 경기선행지수, 무담보콜금리(1일물), 소비자물가지수(CPI), KOSPI, 주택매매 가격지수 등의 자료가 사용된다. 이때 경기를 대리하는 변수로 선행지수, 정책금리를 대리하는 변수로 무담보콜금리를 선정하였으며, 주택매매가격지수는 전국, 서울, 지방, 6개 광역시, 9개 도로 구분하여 각각 사용된다. KOSPI와 콜금리를 제외한 각 변수들은 계절조정된 자료를 사용 한다. 분석기간은 외환위기 이후 글로벌 금융위기 기간까지 주택가격이 금리 변화에 관계없이 꾸준히 상승하여 관계를 왜곡시킬 수 있다는 점을 감안하여 2010년 2월부터 2019년 5월까지 
로 설정한다.

먼저〈그림 1〉과〈표 1〉은 분석에 사용되는 변수들의 추이를 보여준다. 선행지수의 경우 2016년에 단기적으로 주춤하는 모습을 보이고, 2018년 이후로는 상승세가 줄어들지만 전반적 으로 꾸준히 증가하고 있다. CPI는 주기적인 변동폭을 보이고 있으나 상승하는 추세를 보여준 다. 콜금리의 경우 2011년 말까지 3.25\% 수준을 유지하다가 이후 지속적으로 감소하여 2016 년에는 $1.25 \%$ 까지 하락했다. 이후 미국의 금리인상에 따라 2019 년 5월 기준으로 $1.75 \%$ 까지 상승한다. KOSPI의 경우 2017년부터 상승하는 모습을 보인 후, 2017년 말부터는 다시 하락 하였으며 전반적으로 횡보하고 있다. 주택매매가격지수 중 전국과 지방, 6 개 광역시, 9개 도는 2011년 잠시 하락한 이후 현재까지 꾸준히 상승해오다가 최근 상승세가 꺾이고 있다. 2011년 의 주택가격 하락은 저축은행의 과도한 PF대출로 인한 대규모 영업정지가 부동산 시장의 불황 으로 이어진 것이 원인으로 보인다. 반면 서울의 주택매매가격지수는 2011년 하락폭이 타 지 역보다 크고 회복하는 속도도 더딘 반면 2017년부터는 상승폭이 급증하다가 최근 주춤하고 있 다. 특히, 서울에 집중된 투기지역 선정, 부동산 담보대출 규제 등 투기억제를 위한 정책이 2011년부터 2017년까지는 주택가격 상승을 일부분 억제했다고 볼 수 있으나 이후에는 오히려 급증하고 있어 추가적인 원인과 대책을 강구할 필요가 있는 것으로 생각된다.

\section{<표 1> 금리와 주택가격지수 변화율(\%)의 기초통계량}

\begin{tabular}{c|c|c|c|c|c|c|c}
\hline & 평균 & 표준편차 & 왜도 & 첨도 & 최대값 & 최소값 & $\mathrm{Q}(10)$ \\
\hline 선행지수 & 4.576 & 0.105 & 0.108 & 1.624 & 4.740 & 4.419 & $921.62^{* *}$ \\
\hline $\mathrm{CPI}$ & 4.595 & 0.041 & -0.520 & 2.610 & 4.661 & 4.502 & $779.55^{* *}$ \\
\hline 콜금리 & 2.098 & 0.684 & 0.308 & 1.755 & 3.260 & 1.220 & $991.05^{* *}$ \\
\hline $\mathrm{KOSPI}$ & 7.615 & 0.093 & 0.409 & 3.383 & 7.837 & 7.377 & $465.20^{* *}$ \\
\hline$H P I^{\text {적ㄱㄱㄱ }}$ & 4.556 & 0.041 & -0.277 & 2.147 & 4.616 & 4.476 & $801.86^{* *}$ \\
\hline$H P I^{\text {서울 }}$ & 4.560 & 0.049 & 0.756 & 2.841 & 4.670 & 4.495 & $819.32^{* *}$ \\
\hline$H P I^{\text {지방 }}$ & 4.544 & 0.070 & -1.444 & 4.045 & 4.605 & 4.354 & $731.87^{* *}$ \\
\hline$H P I^{\text {6개 광역시 }}$ & 4.537 & 0.063 & -0.815 & 2.876 & 4.610 & 4.383 & $769.25^{* *}$ \\
\hline$H P I^{\text {9개도 }}$ & 4.564 & 0.036 & -0.772 & 2.688 & 4.605 & 4.484 & $790.36^{* *}$ \\
\hline
\end{tabular}

주 1) $H P I$ 는 각각 주택매매 및 전세가격지수를 나타낸다.

2) **,*, + 는 각각 $1 \%, 5 \%, 10 \%$ 수준에서의 신뢰수준을 의미한다. 


\section{<그림 1> 변수의 추이}
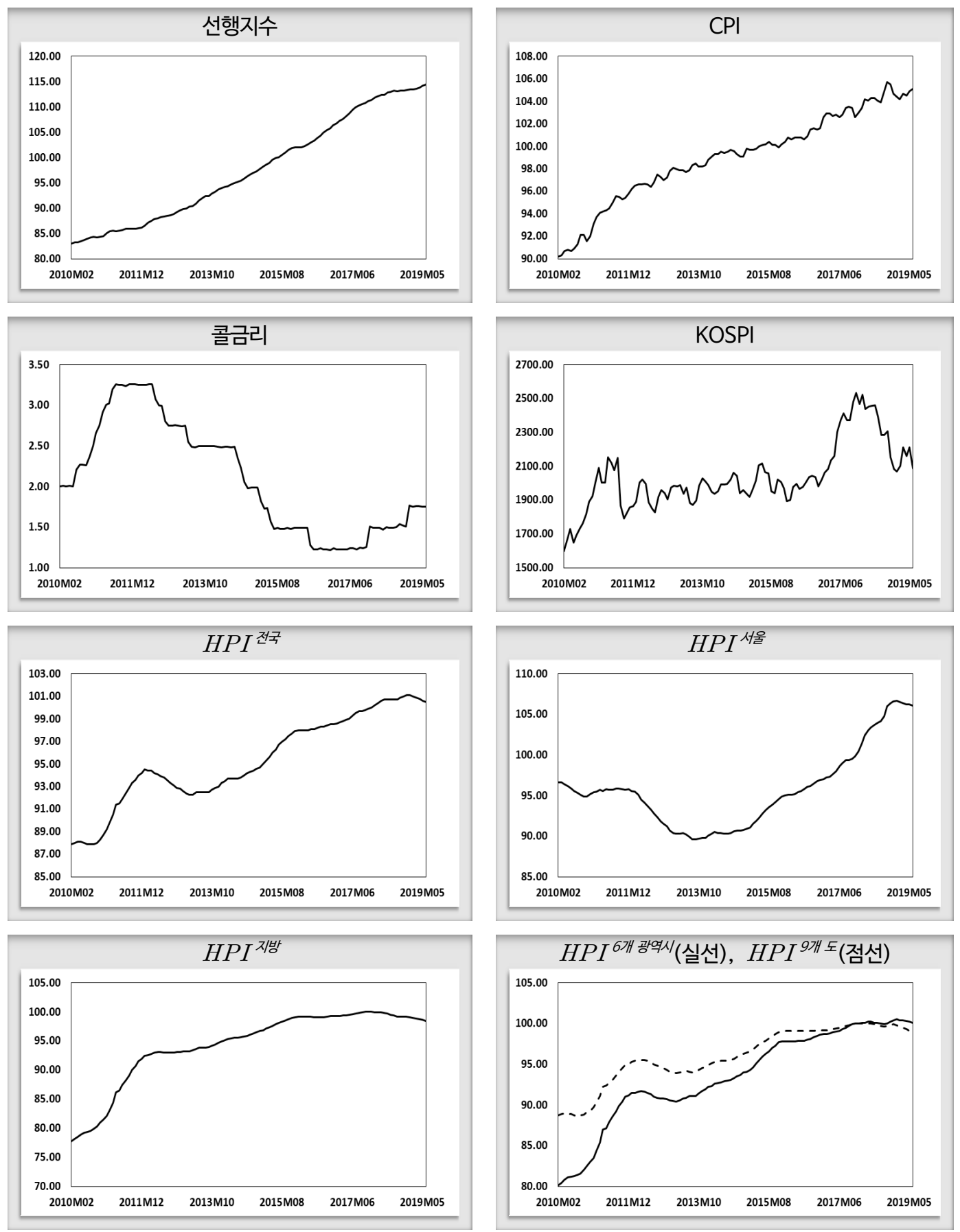


\section{<표 2> 단위근 검정}

\begin{tabular}{|c|c|c|c|c|c|}
\hline \multirow{2}{*}{\multicolumn{2}{|c|}{ 변수 검정방법 }} & \multicolumn{2}{|c|}{ ADF } & \multicolumn{2}{|c|}{ PP } \\
\hline & & 상수 & 추세 & 상수 & 추세 \\
\hline \multirow{9}{*}{$\begin{array}{l}\text { 수준 } \\
\text { 변수 }\end{array}$} & 콜금리 & -0.740 & -2.086 & -0.901 & -2.133 \\
\hline & 전국 매매가격지수 & -1.839 & $-3.421^{+}$ & -1.471 & -2.066 \\
\hline & 서울 매매가격지수 & -0.237 & -1.500 & 0.713 & -0.873 \\
\hline & 지방 매매가격지수 & $-3.368^{*}$ & -2.501 & $-4.514^{* *}$ & -1.894 \\
\hline & 6개 광역시 매매가격지수 & -2.284 & -2.612 & $-2.965^{*}$ & -2.085 \\
\hline & 9개 도 매매가격지수 & -2.111 & -1.670 & -2.239 & -1.468 \\
\hline & 소비자물가지수 & $-3.299^{*}$ & -3.012 & $-4.583^{* *}$ & -3.018 \\
\hline & KOSPI & $-2.749^{+}$ & -2.837 & $-2.776^{+}$ & -3.007 \\
\hline & 선행지수 & -0.219 & -2.241 & 0.183 & -2.015 \\
\hline
\end{tabular}

주) **, *, + 는 각각 $1 \%, 5 \%, 10 \%$ 수준에서의 신뢰수준을 의미한다.

\section{<표 3> 공적분 검정(시차 1)}

\begin{tabular}{|c|c|c|c|c|c|c|c|}
\hline 변수 & $H_{0}$ & 모형 & $\lambda_{\max }$ & Critical value & Trace & Critical value & $r$ \\
\hline $\begin{array}{c}\text { 선행지수, CPI, 콜금리, } \\
\text { KOSPI, HPI 전국 }\end{array}$ & $r=0$ & 상수,추세 & $41.867^{* *}$ & 38.331 & $100.820^{* *}$ & 88.804 & 1 \\
\hline $\begin{array}{c}\text { 선행지수, } \mathrm{CPI} \text {, 콜금리, } \\
\text { KOSPI, HPI }\end{array}$ & $r \leq 3$ & 상수,추세 & $23.144^{*}$ & 19.387 & $32.980^{* *}$ & 25.872 & 4 \\
\hline $\begin{array}{l}\text { 선행지수, } \mathrm{CPI} \text {, 콜금리, } \\
\text { KOSPI, } H P I^{\text {지앙 }}\end{array}$ & $r \leq 2$ & 상수,추세 & $26.339^{*}$ & 25.823 & $47.646^{*}$ & 42.915 & 3 \\
\hline $\begin{array}{l}\text { 선행지수, } \mathrm{CPI} \text {, 콜금리, } \\
\mathrm{KOSPI}, H P I^{6 ㄱ ㅐ ~ ㄱ ㅘ ㅇ ㅇ ㅕ ㄱ ㅅ ㅣ ~}\end{array}$ & $r=0$ & 상수,추세 & $44.015^{* *}$ & 38.331 & $110.087^{* *}$ & 88.804 & 1 \\
\hline $\begin{array}{l}\text { 선행지수, CPI, 콜금리, } \\
\text { KOSPI, HPI }\end{array}$ & $r=0$ & 상수,추세 & $42.087^{*}$ & 38.331 & $106.296^{* *}$ & 88.804 & 1 \\
\hline
\end{tabular}

주 1) $H P I$ 는 각각 주택매매 및 전세가격지수를 나타낸다.

2) **, *, + 는 각각 $1 \%, 5 \%, 10 \%$ 수준에서의 신뢰수준을 의미한다.

실증분석에 앞서 각 변수들의 안정성을 확인하기 위해 $\mathrm{ADF}(\mathrm{Dickey}$ and Fuller, 1979) 검 정과 $\mathrm{PP}(\mathrm{Phillips}$ and Perron, 1988) 검정을 실시한다. 이 때 오차항의 자기상관시차는 Newey and West(1987)를 기준으로 한다. 〈표 2〉는 단위근 검정결과를 보여주는데, 추세를 고려하지 않는 경우 지방 주택매매가격지수, 소비자물가지수, KOSPI에서 단위근이 존재하지 않는 것으로 나타난다. 반면 추세를 고려하면 $\mathrm{ADF}$ 검정에서만 전국 매매가격지수의 단위근이 
존재한다는 귀무가설이 $10 \%$ 수준에서 기각된다. 하지만 추세를 고려한 PP검정 결과, 모든 변 수가 단위근이 존재하는 것으로 나타난다. 단위근이 존재하는 변수를 이용하여 분석하는 경우 공적분 관계가 나타날 수 있으므로 여기서는 Johansen(1988)의 검정을 이용한다. 〈표 3〉으로 부터 분석에 사용되는 변수 조합으로 선행지수, $\mathrm{CPI}$, 콜금리, $\mathrm{KOSPI}$ 와 전국, 서울, 지방, 6개 광역시, 9개 도의 주택매매가격지수로 구성된 5변수의 공적분 검정결과를 살펴보면 모든 경우 에 공적분이 1 개 이상 존재하는 것으로 나타난다. 공적분이 존재하는 경우 각 변수 간 선형결합 은 안정성을 갖기 때문에 본 연구에서는 정보가 소실될 수 있는 차분변수보다 수준변수를 활용 한 VAR 모형 및 Jorda(2005)의 국소투영모형을 이용하여 분석하기로 한다.1)

\section{IV. 추정방법}

앞서 이야기 한 바와 같이 본 연구에서는 공적분 관계가 있는 변수들의 수준변수로 구성된 VAR 모형을 추정한다. 이 경우 올바른 충격반응함수를 도출하기 위해 일반적인 VAR 모형의 충격반응함수와 함께 Jorda(2005)의 국소투영에 근거하여 충격반응을 계산한다. Jorda(2005) 의 충격반응함수는 식(1)과 같이 직접적인 예측모형을 통해 매 시점마다 예측범위를 재추정하 여 예측치의 정확도를 높일 수 있다. Jorda(2005)는 전기의 $y$ 에 대한 다항식을 고려한 국소입 방투영모형(local cubic projection model)을 이용한다.

$$
Y_{t+p}=\beta_{0}^{p}+\beta_{1}^{p+1} Y_{t-1}+\gamma_{1}^{p+1} Y_{t-1}^{2}+\delta_{1}^{p+1} Y_{t-1}^{3}+\beta_{2}^{p+1} Y_{t-2}+\cdots \beta_{p}^{p+1} Y_{t-p}+\varepsilon_{t+p}^{p}
$$

식 (1)의 $\mathrm{p}$ 시점에서의 충격반응함수는 식 (2)와 같이 나타낼 수 있다.

$$
\begin{aligned}
\operatorname{IRF}\left(t, p, d_{i}\right) & =\left[\hat{\beta}_{1}^{p}\left(Y_{t-1}+d_{i}\right)+\hat{\gamma}_{1}^{p}\left(Y_{t-1}+d_{i}\right)^{2}+\hat{\delta}_{1}^{p}\left(Y_{t-1}+d_{i}\right)^{3}\right]-\left[\hat{\beta}_{1}^{p} Y_{t-1}+\hat{\gamma}_{1}^{p} Y_{t-1}^{2}+\hat{\delta}_{1}^{p} Y_{t-1}^{3}\right] \\
& =\left[\hat{\beta}_{1}^{p} d_{i}+\hat{\gamma}_{1}^{p}\left(2 Y_{t-1} d_{i}+d_{i}^{2}\right)+\hat{\delta}_{1}^{p}\left(3 Y_{t-1}^{2} d_{i}+3 Y_{t-1} d_{i}^{2}+d_{i}^{3}\right)\right], p=0,1,2, \ldots, T
\end{aligned}
$$

식 (2)에서 $Y$ 의 2차 항과 3차 항의 계수인 $\hat{\beta}_{i}^{p}$ 나 $\hat{\gamma}_{i}^{p}$ 가 0이 아닌 경우 충격반응함수의 충격의

1) 이근영(2010)에서도 공적분이 존재하는 변수들의 수준변수를 이용하여VAR모형을 추정하고 있다. Hansen (2000)에 따르면 공적분 관계가 있는 변수의VAR 모형으로부터 올바른 충격반응함수를 도출하는 것은 쉽지 않 지만, Jorda(2005)의 국소투영모형의 경우에는 이러한 제약에서 벗어날 수 있다. 
방향과 크기에 따라 변하게 된다. 또한 이 때의 충격반응함수는 $Y_{t-1}$ 에 의존하게 되는데 이는 최근에 정보의 영향이 많이 반영된다는 것을 의미한다.

국소투영모형 충격반응함수의 95\% 신뢰구간은 식 (3)과 같이 계산할 수 있다.

$$
1.96 \pm \phi_{i}^{\prime} \hat{\Omega}_{C} \phi_{i}
$$

식 (3)에서 $\phi_{i}=\left(d_{i}, 2 Y_{t-1} d_{i}+d_{i}^{2}, 3 Y_{t-1}^{2} d_{i}+3 Y_{t-1} d_{i}^{2}+d_{i}^{3}\right), \hat{\Omega}_{C}$ 는 $\beta_{1}^{p}, \gamma_{1}^{p}, \delta_{1}^{p}$ 의 분산-공 분상 행렬이며 Newey and West(1987)에 따라 추정할 수 있다.

\section{V. 충격반응함수}

본 절에서는 경기와 금리의 변화가 주택가격 및 서울과 타 지역 간 주택가격 격차에 미치는 영향을 분석하기 위해 선행지수, $\mathrm{CPI}$, 콜금리, $\mathrm{KOSPI}$, 주택매매가격지수의 5변수로 구성된 VAR 모형을 추정한다. 또한 잘 알려져 있듯이 경기나 금리의 상승과 하락이 주택매매가격지수 에 미치는 영향이 다르기 때문에 이러한 비대칭성을 반영할 수 있는 국소투영모형을 추정한다. 이 때 시차는 SIC를 기준으로 하여 1 또는 2 인 경우를 추정한다. VAR 모형을 이용하여 충격반 응함수를 분석하는 경우 변수의 순서에 따라 그 결과가 달라질 수 있기 때문에 여기서는 충격의 영향에 시차가 있는 실물변수인 선행지수와 $\mathrm{CPI}$ 를 앞에 두고, 즉각적인 반응을 보이는 금융변 수인 콜금리와 $\mathrm{KOSPI}$ 를 다음 순서로 설정한다. 본 연구에서 주로 보고자 하는 주택매매가격지 수는 마지막으로 설정한다. VAR 모형과 국소투영모형의 충격반응함수는 〈그림 2〉 〈그림 8〉 에 나타나 있는데 그림에서 LEAD+ 와 LEAD-는 선행지수의 양(+)의 충격과 음(-)의 충격을 나 타낸다. 마찬가지로 CALL+와 CALL-는 콜금리의 양(+)의 충격과 음(-)의 충격을 의미한다. 두 번째 행에 있는 LEAD+와 CALL+ 등은 선행지수와 콜금리 충격이 동시에 나타난 경우를 의 미한다. 본 연구에서는 동시충격 시 충격의 크기가 주택매매가격지수에 미치는 영향을 일정하 게 비교하기 위해 선행지수의 1 표준편차인 0.1 을 충격의 크기로 설정한다. 반면 콜금리는 정책 의 효과를 비교하기 위해 $1 \% \mathrm{p}$ 를 충격의 크기로 가정한다. 또한 실선과 점선은 국소투영모형의 충격반응과 $95 \%$ 신뢰구간을 의미하며, 실전-점은 일반적인 VAR 모형의 충격반응함수를 나타 낸다. 


\section{1. 주택매매가격지수}

먼저 〈그림2〉는 선행지수와 콜금리의 충격에 대한 서울 주택매매가격지수의 반응을 보여준 다. 선행지수의 양(+)의 충격과 음(-)의 충격은 서울 주택매매가격지수를 각각 상승 또는 하락 시키고 18 개월 후부터는 그 반응의 방향이 역전된다. 다만 반응의 크기는 선행지수의 양 $(+)$ 의 충격이 최대 0.1 이 넘는 반면, 음(-)의 충격이 최대 -0.1 보다 작은 수준으로 차이가 크지는 않 지만 선행지수에 대한 상승충격의 영향이 크다. 콜금리의 경우 양(+)의 충격 시 서울 주택매매 가격지수가 단기적으로는 상승하지만 3 개월 후부터는 하락하는 반응을 보이기 시작하며 16 개 월 후 -0.05 로 가장 낮아진다. 반대로 콜금리의 음(-)의 충격 시에는 초기에 하락한 후 3 개월 후부터 상승하기 시작하여 24개월 후에는 최대 0.07 까지 상승한다. 즉, 콜금리에 대한 상승충 격보다 하락충격의 영향이 크게 나타난다. 다음으로 선행지수와 콜금리에 동시 충격이 발생한 경우를 살펴본다. 우선 선행지수와 콜금리가 서울 주택매매가격지수에 미치는 영향이 반대로 나타나기 때문에 같은 방향의 충격은 그 영향이 상쇄되어 나타날 가능성이 크다. 실제로 충격반 응도 횡보하는 형태로 나타난다. 반대로 두 변수의 충격의 반응이 다른 경우에는 그 영향이 확 대되어 나타나게 된다. 그 결과를 살펴보면, 선행지수의 양(+)의 충격과 콜금리의 음(-)의 충격 이 동시에 나타나는 경우 서울 주택매매가격지수는 꾸준히 상승하여 22개월 후에는 최대 0.16 까지 증가한다. 반면 선행지수의 음(-)의 충격과 콜금리의 양(+)의 충격이 동시에 나타나는 경 우에는 서울 주택매매가격지수가 꾸준히 하락하여 16 개월 후 -0.14 까지 하락한다.

\section{<그림 2> 선행지수(LEAD)와 콜금리(CALL)의 동시 충격(서울)}

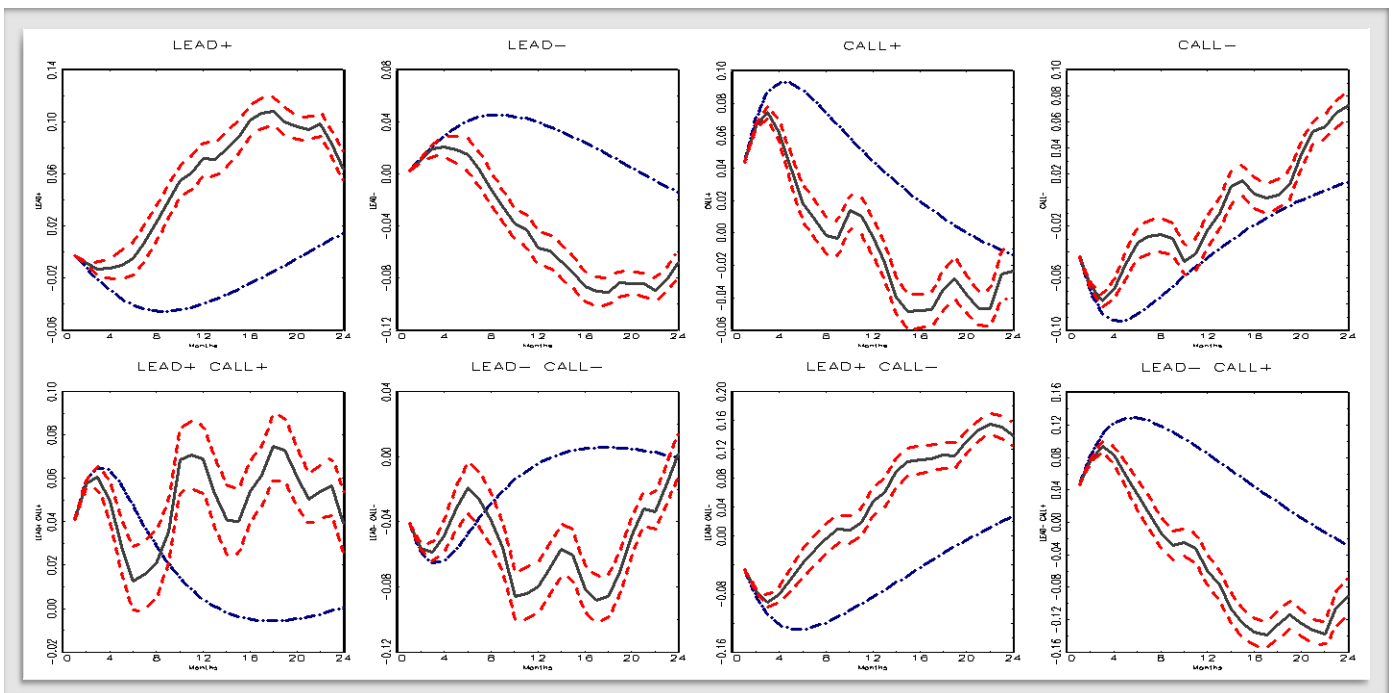


<그림 3> 선행지수(LEAD)와 콜금리(CALL)의 동시 충격(지방)

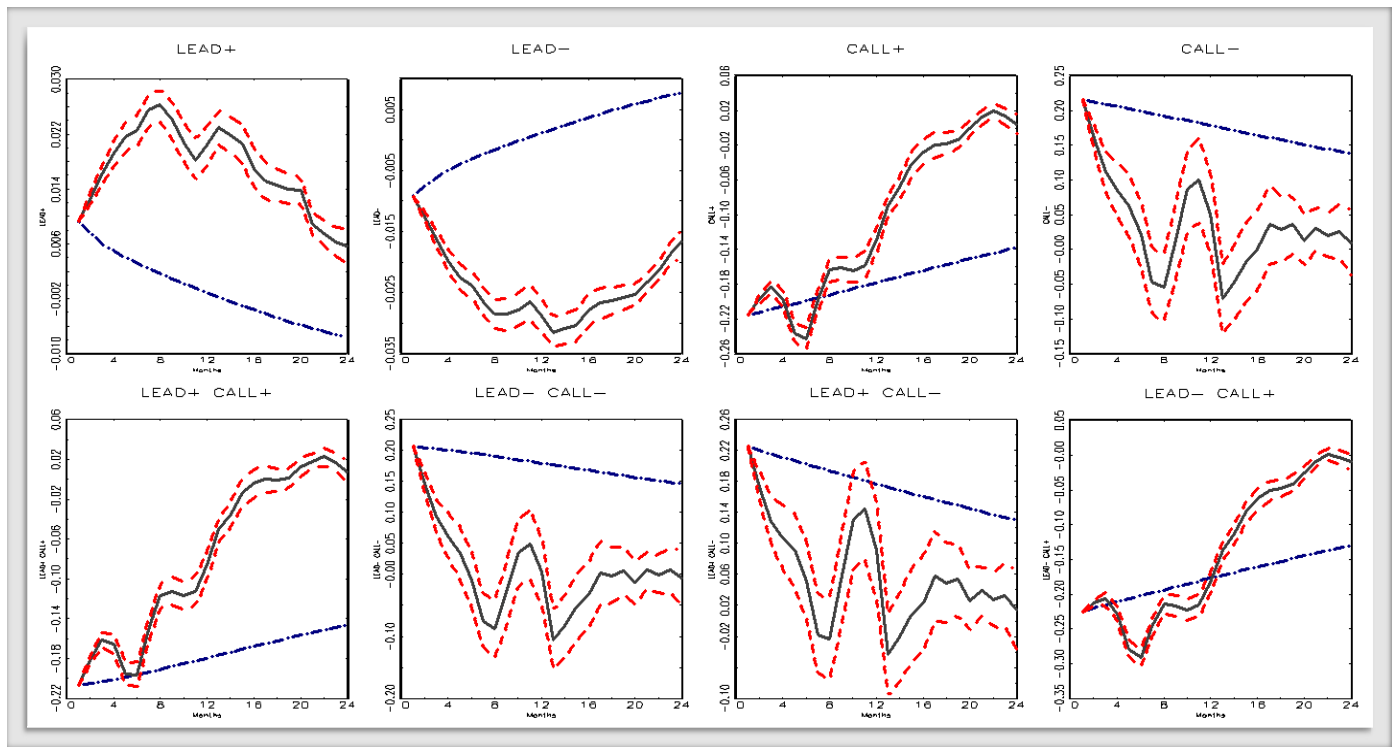

<그림 4> 선행지수(LEAD)와 콜금리(CALL)의 동시 충격(6개 광역시)
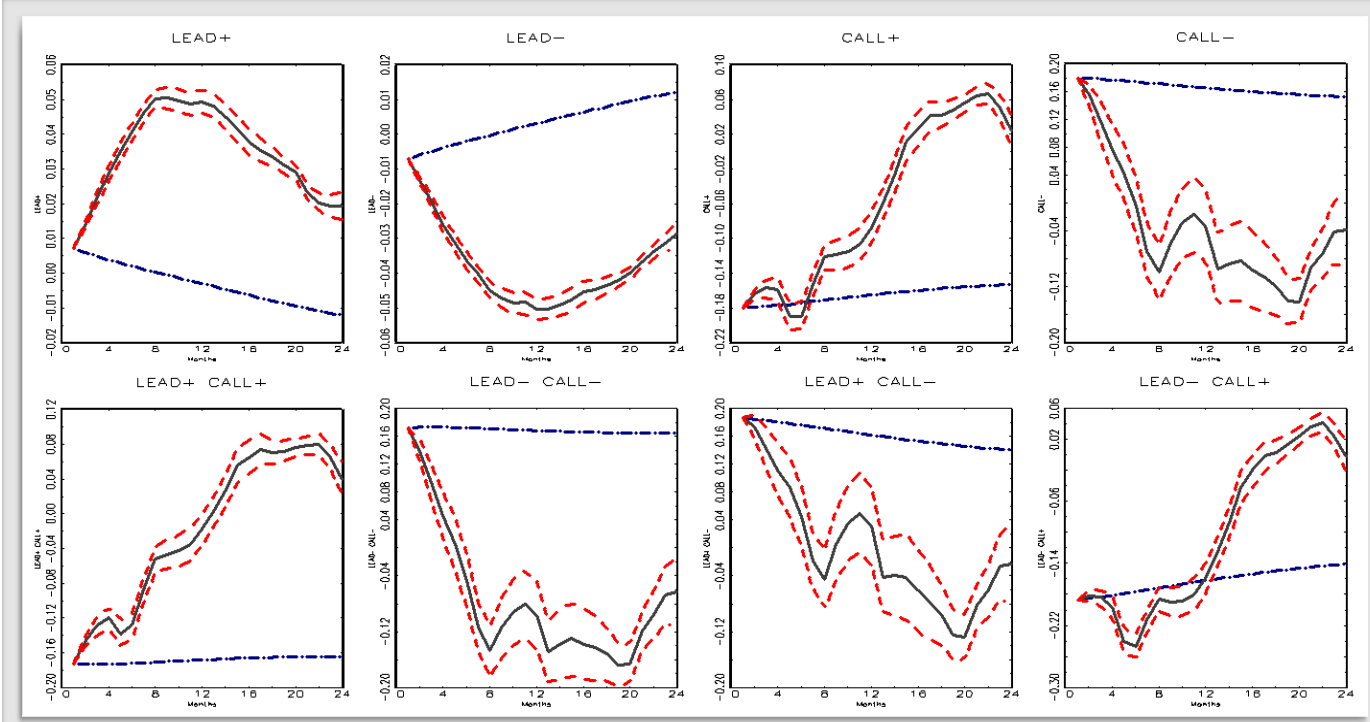


\section{<그림 5> 선행지수(LEAD)와 콜금리(CALL)의 동시 충격(9개 도)}

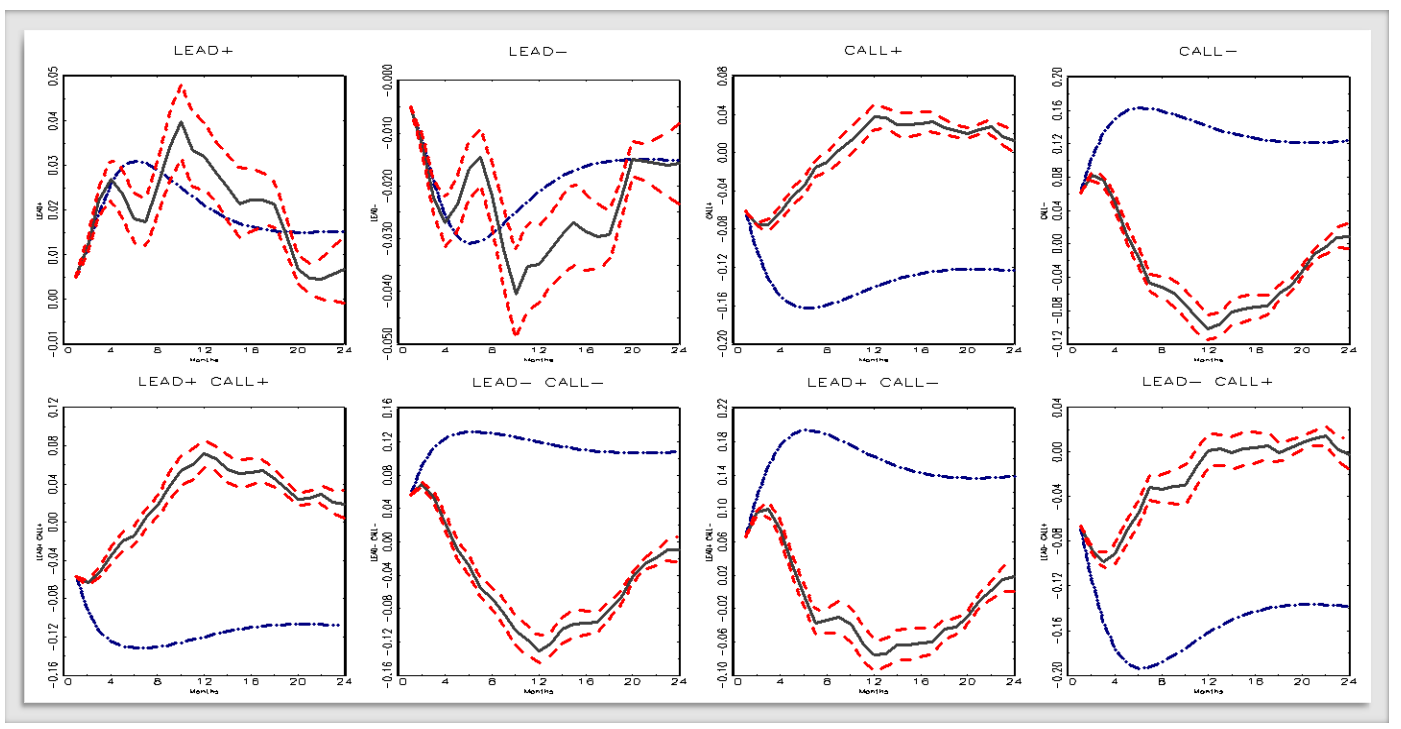

〈그림 3〉 〈그림 5〉에서는 타 지역 주택매매가격지수의 반응을 보여주는데 서울 주택매매 가격지수와는 달리 지방, 6 개 광역시, 9개 도에서는 그 결과가 다르게 나타난다. 세부적으로 선 행지수의 충격에 대한 반응의 방향은 동일하나 콜금리의 충격에 대한 반응의 방향이 다르다. 기 존의 연구와 같이 분석기간을 외환위기 이전까지 늘리는 경우에는 콜금리 상승이 주택가격을 하락시키는 것처럼 나타나지만 분석기간을 2010년 이후로 한정하는 경우에는 본 연구의 결과 와 같이 콜금리의 양(+)의 충격이 주택가격을 오히려 상승시키는 것으로 나타난다. 실제로 금리 가 주택가격에 미치는 영향이 직접적일 수는 있지만 주택가격의 결정요인은 금리 외에도 많은 요소들이 있기 때문에 반드시 둘 간의 관계가 음(-)의 관계라고 가정하는 것에는 무리가 따른 다. 특히나 최근과 같이 서울과 경기, 충북지역을 제외한 타 지역의 고령화나 인구이탈에 따른 인구구조의 변화가 극심한 상황에서는 투기수요가 적고 실수요가 많을 수 있기 때문에 오히려 금리의 영향이 낮게 나타날 수 있다. 이러한 배경에서 경기가 하락함에도 주택가격의 과도한 상 승이나 금융시장의 안정을 위한 해외 통화정책과의 공조 등으로 인해 경기침체가 예상됨에도 금리를 인하시키지 못하고 인상시키는 경우에는 서울과 타 지역의 주택매매가격지수의 차이가 더 증대될 수 있다. 물론 반대로 경기과열을 억제하기 위해 금리를 인상시켜 경기수준이 다시 하락하게 되는 경우에도 마찬가지로 그 차이가 증가하게 된다. 반면, 경기가 상승함에도 금리를 인하시켜야 하는 경우나 경기침체를 완화하기 위해 콜금리를 인하하여 경기수준이 회복되는 경 우도 동일하다. 〈그림 3〉 〈그림 5〉에서도 유사한 결과를 나타내고 있는데 선행지수의 상승충 
격과 콜금리의 하락충격이 동시에 발생할 때, 주택가격의 하락하고, 반대로 선생지수의 하락충 격과 콜금리의 상승충격이 동시에 발생할 때, 주택가격은 상승하고 있다.

<그림 6> 선행지수(LEAD)와 콜금리(CALL)의 동시 충격(서울/지방)

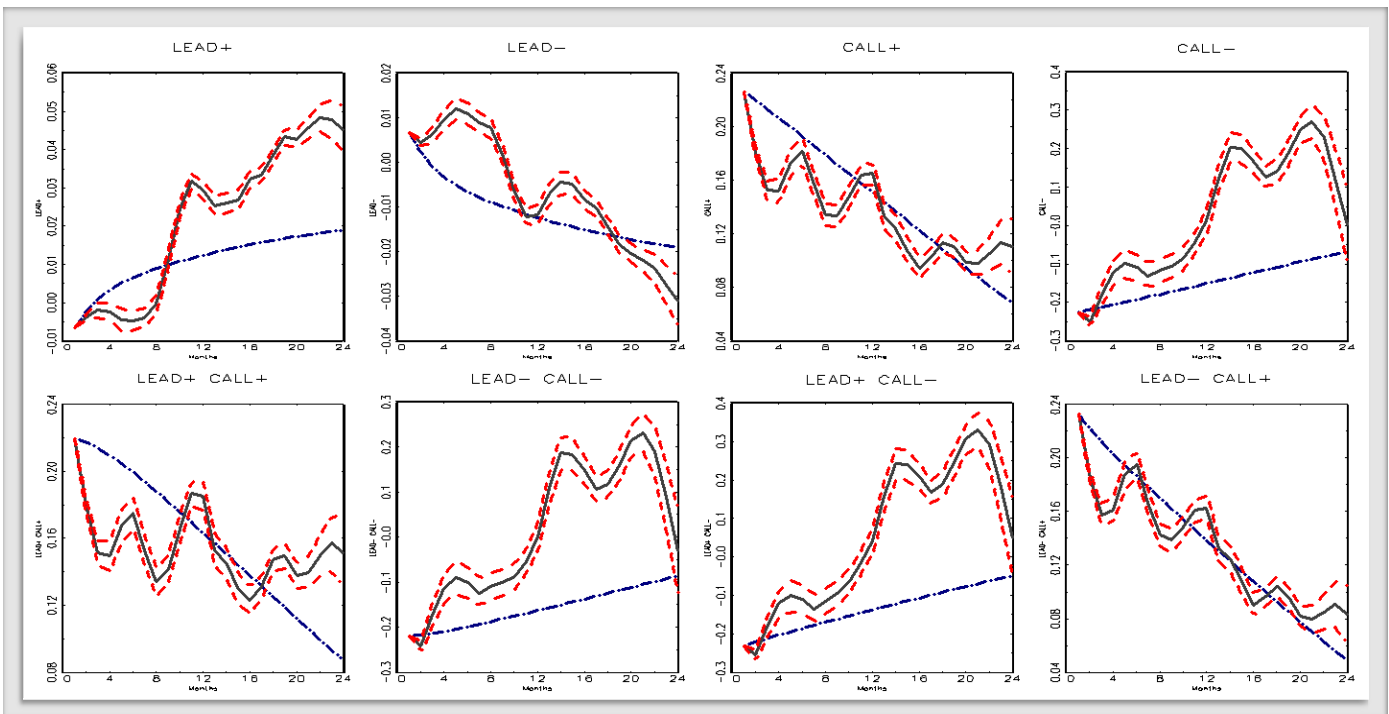

<그림 7> 선행지수(LEAD)와 콜금리(CALL)의 동시 충격(서울/6개 광역시)
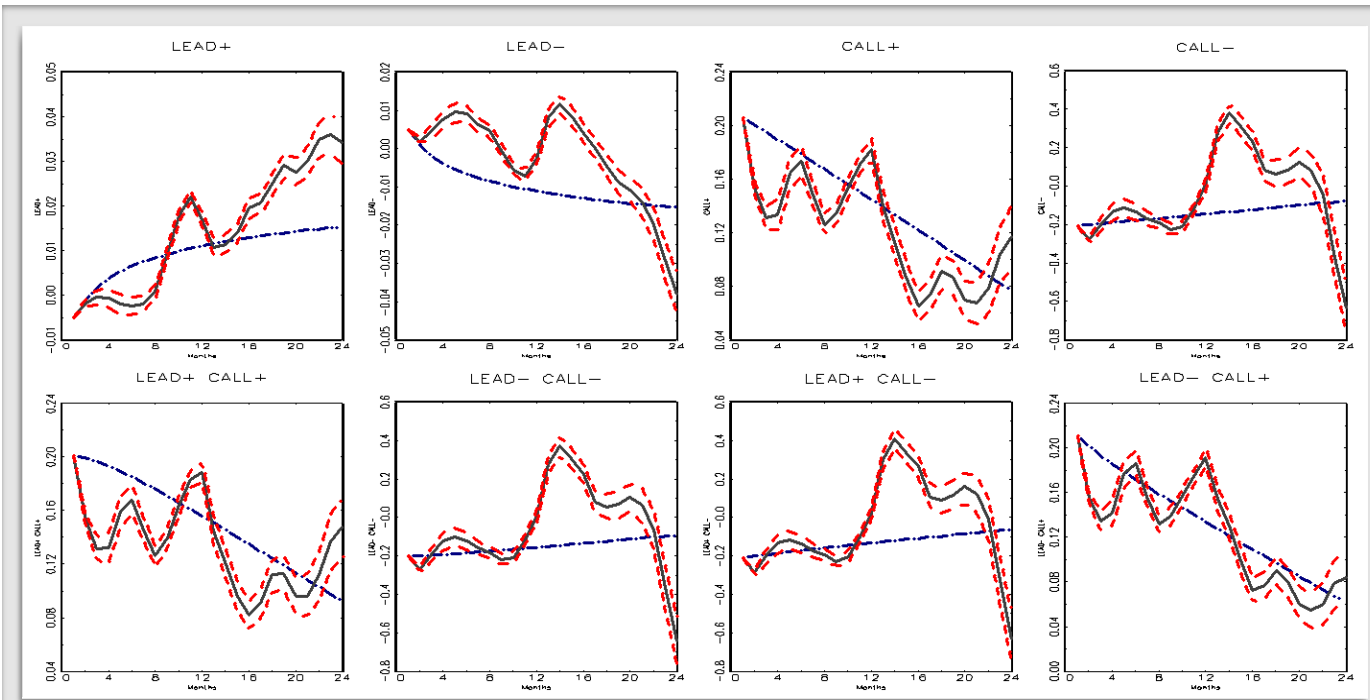


\section{<그림 8> 선행지수(LEAD)와 콜금리(CALL)의 동시 충격(서울/9개 도)}

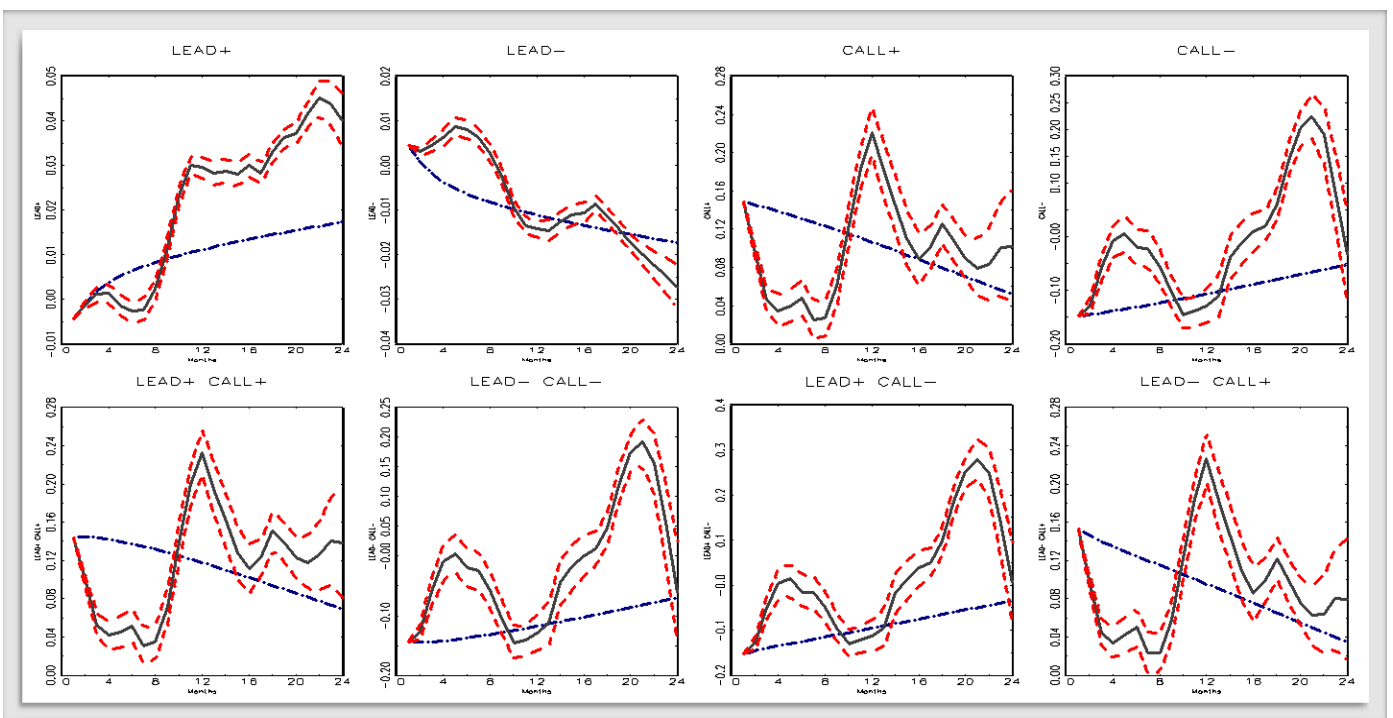

\section{2. 주택매매가격지수 차이}

서울과 타 지역간 주택가격의 차이를 좀 더 직접적으로 확인하기 위해 서울과 타 지역 주택매 매가격지수의 차이를 변수로 하여 동일한 5변수 VAR 모형 및 국소투영모형을 추정한 후 충격 반응함수를 비교해본다. 〈그림 6〉 〈그림 8〉은 각각 서울/지방, 서울/6개 광역시, 서울/9개 도의 반응을 나타낸다. 먼저 선행지수와 콜금리 단독충격을 중심으로 살펴보면, 세 경우 모두 반응에 시차가 존재하지만 전반적으로 선행지수의 양(+)의 충격에 그 차이가 증가하고, 선행지 수의 음(-)의 충격에는 그 차이가 줄어든다. 콜금리의 경우에도 콜금리의 양(+)의 충격에 그 차 이가 증가하나 격차는 점점 감소하며, 콜금리의 음(-)의 충격에도 20 개월까지는 그 차이가 증가 한 후 이후로는 줄어든다. 즉 서울과 타 지역 주택가격간 차이가 증가하는 경우는 경기가 상승 하거나 금리가 상승하는 경우, 중장기적으로는 하락하는 경우까지 해당된다. 이렇게 경기변화 와 금리변화가 서울과 타 지역의 주택가격에 미치는 영향이 다르기 때문에 다음으로는 이들 충 격이 동시에 발생하는 경우를 분석하여 직관적으로 확인해보기로 한다.

선행지수와 콜금리 동시 충격의 경우를 살펴보면, 〈그림 6〉의 서울-지방 주택가격 차이의 경 우 그 차이가 가장 커지는 경우는 선행지수의 상승충격과 콜금리의 하락충격이 동시에 발생하 는 경우로 초기에는 그 차이가 줄어들지만 12 개월 후부터는 서울과 지방 간 주택가격 격차가 
점점 커져 0.3 까지 증가한다. 또한 선행지수의 하락충격과 콜금리의 상승충격이 동시에 발생하 는 경우에도 그 차이가 커지지만 점점 그 격차가 줄어든다. 〈그림 7〉의 6개 광역시와 〈그림 8〉 의 9개 도는 유사한 반응을 보이고 있는데 선행지수의 상승충격과 콜금리의 하락충격이 동시에 발생하는 경우 주택가격 차이가 최대 0.3 0.4까지 증가하나 이후 다시 줄어든다. 반면 선행지 수의 하락충격과 콜금리의 상승충격이 동시에 발생하는 경우에는 둘 모두 차이가 증가하며 그 격차는 12 개월 이후 점차 줄어든다.

\section{VI. 결론}

본 연구에서는 2010년 2월부터 2019년 5월까지의 표본기간동안 선행지수, CPI, 콜금리, $\mathrm{KOSPI}$ 등의 거시 및 금융변수와 전국 및 지역별 주택매매가격지수를 이용한 5변수 VAR 모형 을 추정한다. 이때의 충격반응함수는 Jorda(2005)의 국소투영모형을 이용하여 선행지수와 콜 금리의 상승 또는 하락충격이 전국, 서울, 지역별 주택매매가격지수에 미치는 영향을 비교한다. 또한 선행지수와 콜금리의 동시 충격이 발생하는 경우의 영향에 대해서도 비교한다.

분석결과를 요약하면, 서울 주택매매가격지수의 경우 선행지수의 상승(하락)충격에 대해 주 택가격도 상승(하락)하는 것으로 나타나며 콜금리의 상승(하락)충격에 주택가격은 하락(상승)하 는 반응을 보인다. 서울의 주택가격이 가장 큰 반응을 보이는 경우는 선행지수의 상승충격과 콜 금리의 하락충격이 동시에 발생하는 경우이며 주택가격은 상승한다. 다음으로는 선행지수의 하 락충격과 콜금리의 상승충격이 동시에 나타나는 경우로 주택가격은 하락한다. 반면 서울을 제 외한 지방, 6 개 광역시, 9개 도의 경우에는 선행지수의 충격에는 서울의 경우와 동일한 방향으 로 나타나나 콜금리의 충격에는 반응의 방향이 같지 않다. 서울을 중심으로 지방, 6개 광역시, 9개 도의 주택매매가격지수 간 차이를 변수로 하여 분석한 결과, 그 격차는 선행지수에 대한 상 승충격, 콜금리의 상승충격 시 증가하고, 장기적으로는 콜금리의 하락충격에도 다소 증가한다.

소규모 개방경제인 우리나라의 경제와 통화정책은 해외의 경제상황에 민감하게 반응할 수밖 에 없다는 점을 생각해볼 필요가 있다. 특히, 최근과 같이 미국의 금리인하에도 한국의 경제는 금리를 인하할 수 없는 상황에 처해있는 경우를 생각해보면 미국의 테이퍼링으로 금리가 인상 되어도 우리나라의 금리가 즉각적으로 인상되기를 기대하기는 힘들다. 금리 정책을 위해서는 고려해야할 요소가 너무 많기 때문이며, 그 중 하나가 부동산 시장, 특히 서울의 주택가격이다. 
또한 본 연구의 분석결과에 적용해보면, 국내 경제상황이 악화된 상황에도 외부의 여건에 따라 금리를 인상하는 경우에는 주택가격이 급격하게 하락할 수 있고, 특히 서울의 주택가격은 지속 적인 하락을 경험 할 수도 있다. 반대로 국내 경제상황이 양호한 상황에도 금리를 인하하는 경 우 경기가 과열되면서 주택가격도 크게 오를 수 있다. 이러한 반응은 지방보다 서울의 경우 그 영향이 극대화 되어 거품이 점점 커질 가능성이 있다. 이러한 논리는 경제상황이 우선시 된다는 조건이지만 반대로, 금리정책에 의해 경제가 회복되거나 침체되는 경우에도 마찬가지이다. 따 라서 금리를 인하하기에 앞서서 현재의 경제상황을 고려한 부동산 정책규제를 통해 주택가격 과열을 사전에 방지하거나 금리를 인상하기 전에도 주택가격의 과도한 폭락에 대비할 필요가 있다.

\section{참교문헌}

김남현·장한익, 2018, “금리가 주택가격에 미치는 영향과 요인”, 주택금융연구, 제2호, 5-39.

박송춘, 2009, "RP금리가 부동산 가격에 미치는 파급효과에 관한 연구”, 한국비지니스리뷰, 제2권 제1호, 157-174.

손종칠, 2010, “통화정책 및 실물·금융변수와 주택가격간 동태적 상관관계 분석”, 경제학연구 제58집 제 2호, 179-219.

이근영·김남현, 2016, “금리와 주택가격”, 경제학연구 제64호 제4호, 45-82.

장한익, 2019, “수도권과 지방 주택매매가격의 동조화 변화 분석”, LHI Journal, 제12권 제1호, 9-18. 전해정, 2014, “글로벌 금융위기 전·후로 거시경제변수와 부동산 시장 간의 관계에 대한 연구”, 부동산학보, 33-44.

황영진, 2015, “한국 주택 가격의 경기 순환: 특징 및 함의", 부동산학연구 제21집 제4호, 19-33.

Bernanke, B. S., 2013, "The Federal Reserve and the financial crisis", Princeton University Press.

Cambell, S. D., M. Davis, J. Gallin and R. F. Martin, 2009, "What moves housing markets: A variance decomposition of the rent-price ratio", Journal of Urban Economics 66, 90-102.

Dickey, D. A. and W. A. Fuller, 1979, "Distribution of the estimators for autoregressive time series with a unit root", Journal of the American statistical association, 74(366a), 427-431.

Hansen, B. E., 2000, “Sample Splitting and Threshold Estimation”, Econometrica, 68(3), 575-603.

Himmelberg. C, C. Mayer and T. Sinai, 2005, "Assessing high house prices: bubbles, 
fundamentals and misperceptions", Journal of Economic Perspectives 19, 67-92. Johansen, S., 1988, "Statistical Analysis of Cointegration Vectors", Journal of Economic Dynamics and Control, 12(2-3), 231-254.

Jorda, O., 2005, "Estimation and Inference of Impulse Responses by Local Projections", American Economic Review, 95(1), 161-182.

Maurin, C., A. de Palma and N. Picard, 2012, "Regime Switching Models: An application to the Real Estate Market in Ile de France", SustatinCity Working Paper, 3.5.

Newey, W. K. and K. D. West, 1987, "A Simple Positive Semi-Definite, Heteroskedasticity and Autocorrelation Consistent Covariance Matrix”, Econometrica, 55(3), 703-708.

Nneji, O., C. Brooks and C. Ward, 2013, "House price dynamics and their reaction to macroeconomic changes", Economic Modeling 32, 172-178.

Phillips, P. C. and P. Perron, 1988, "Testing for a unit root in time series regression", Biometrika, 75(2), 335-346.

Taylor, J. B., 2007, "Housing and monetary policy", No. w13682, National Bureau of Economic Research. 
주택금융연구 VOL 3

부록. 지역별 충격반응함수

<그림 $\mathrm{A} 1$ > 선행지수(LEAD)와 콜금리(CALL)의 동시 충격
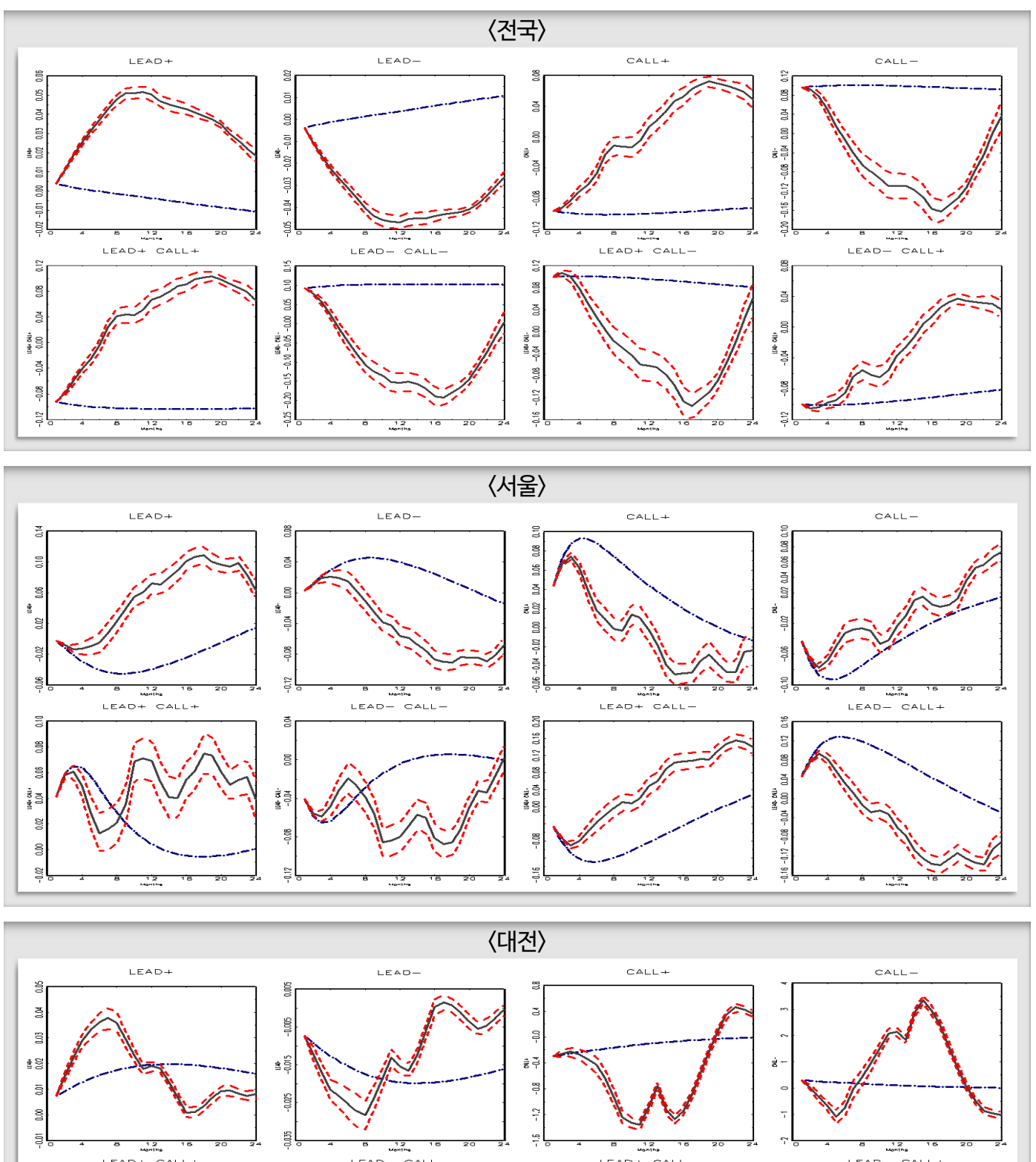

〈대전〉
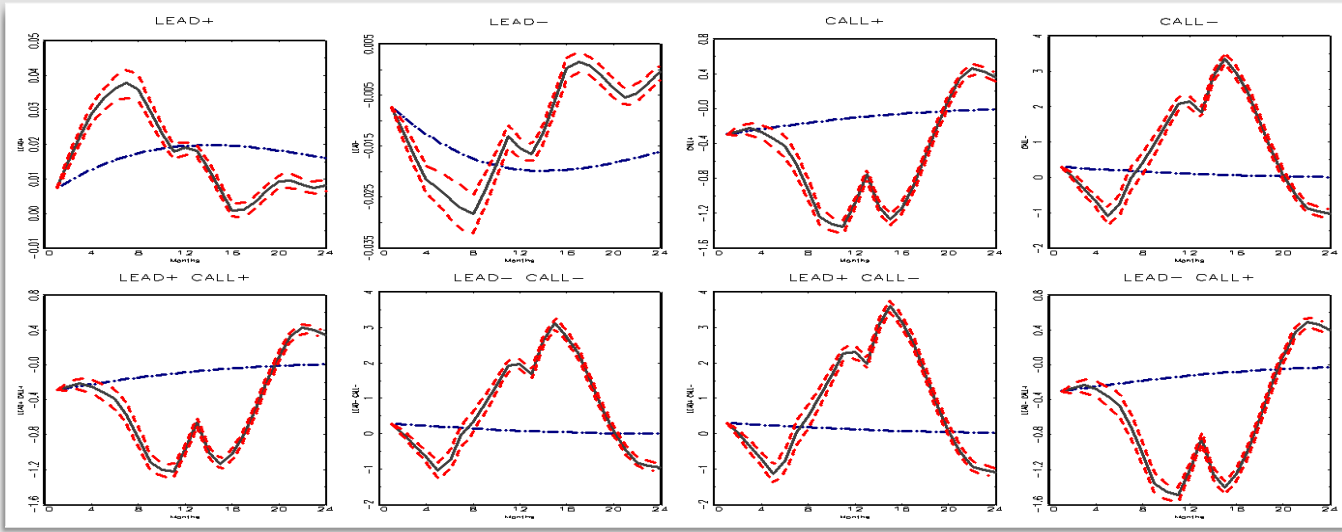

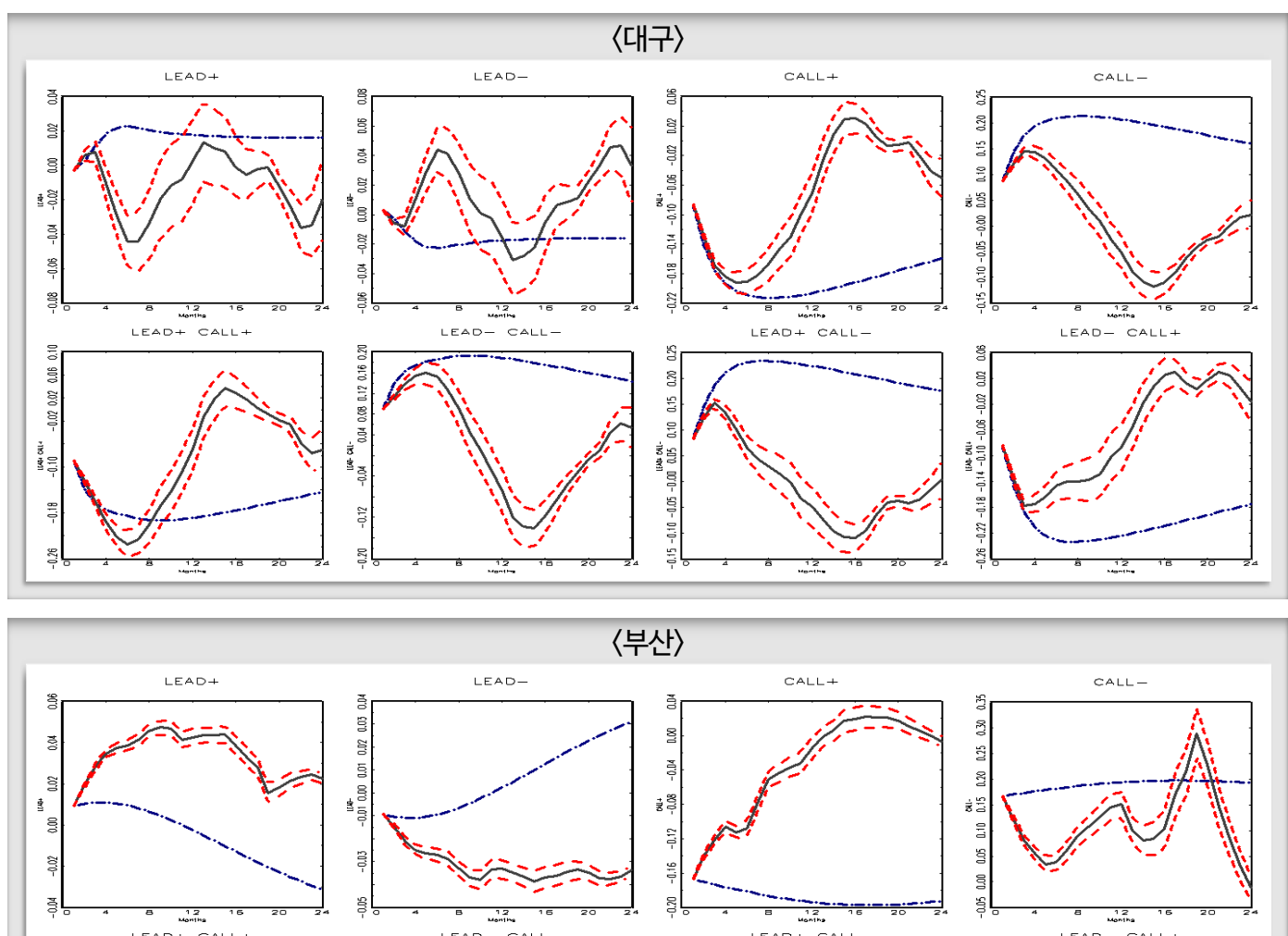

〈부산〉
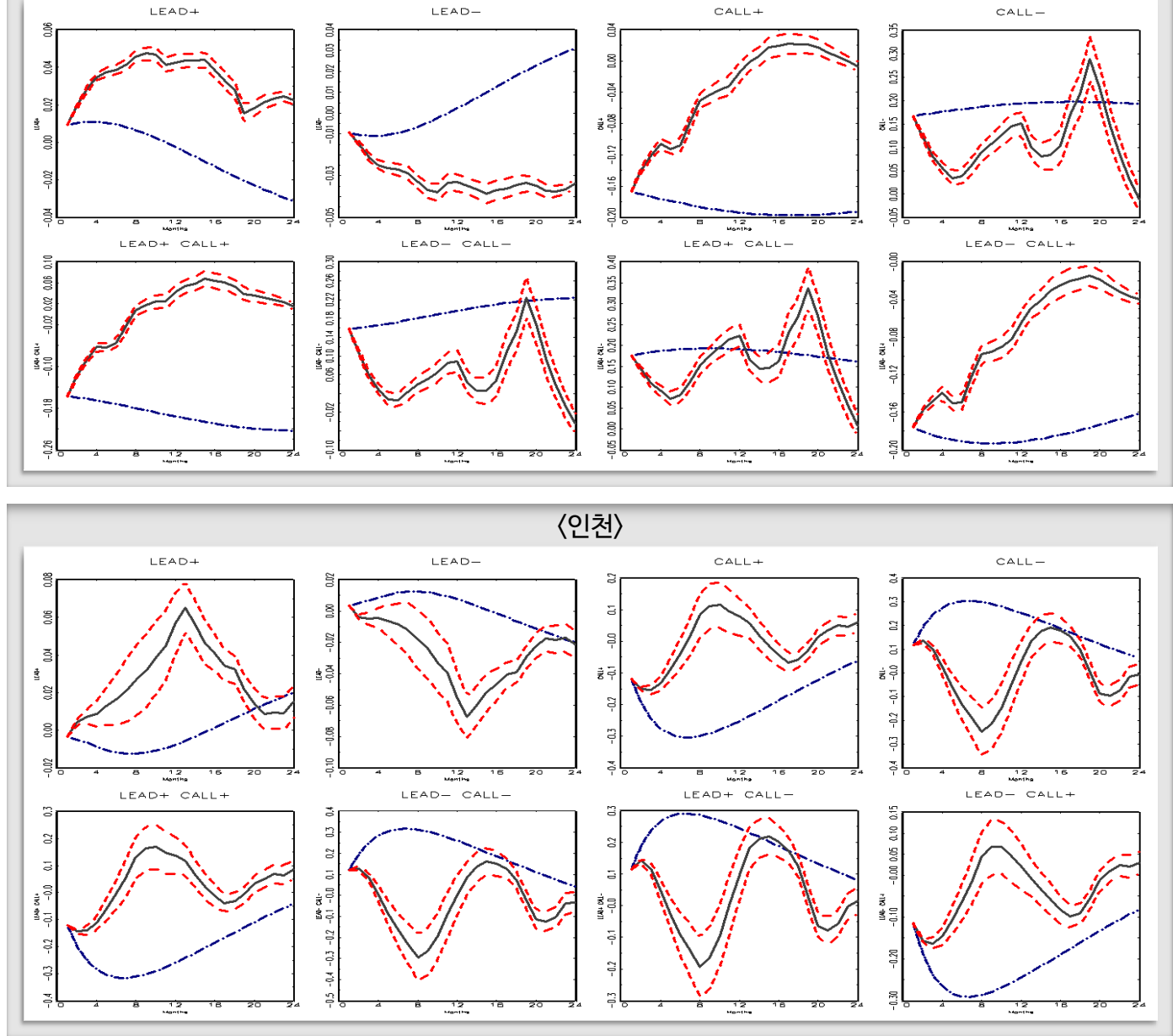
주택금융연구 VOL 3
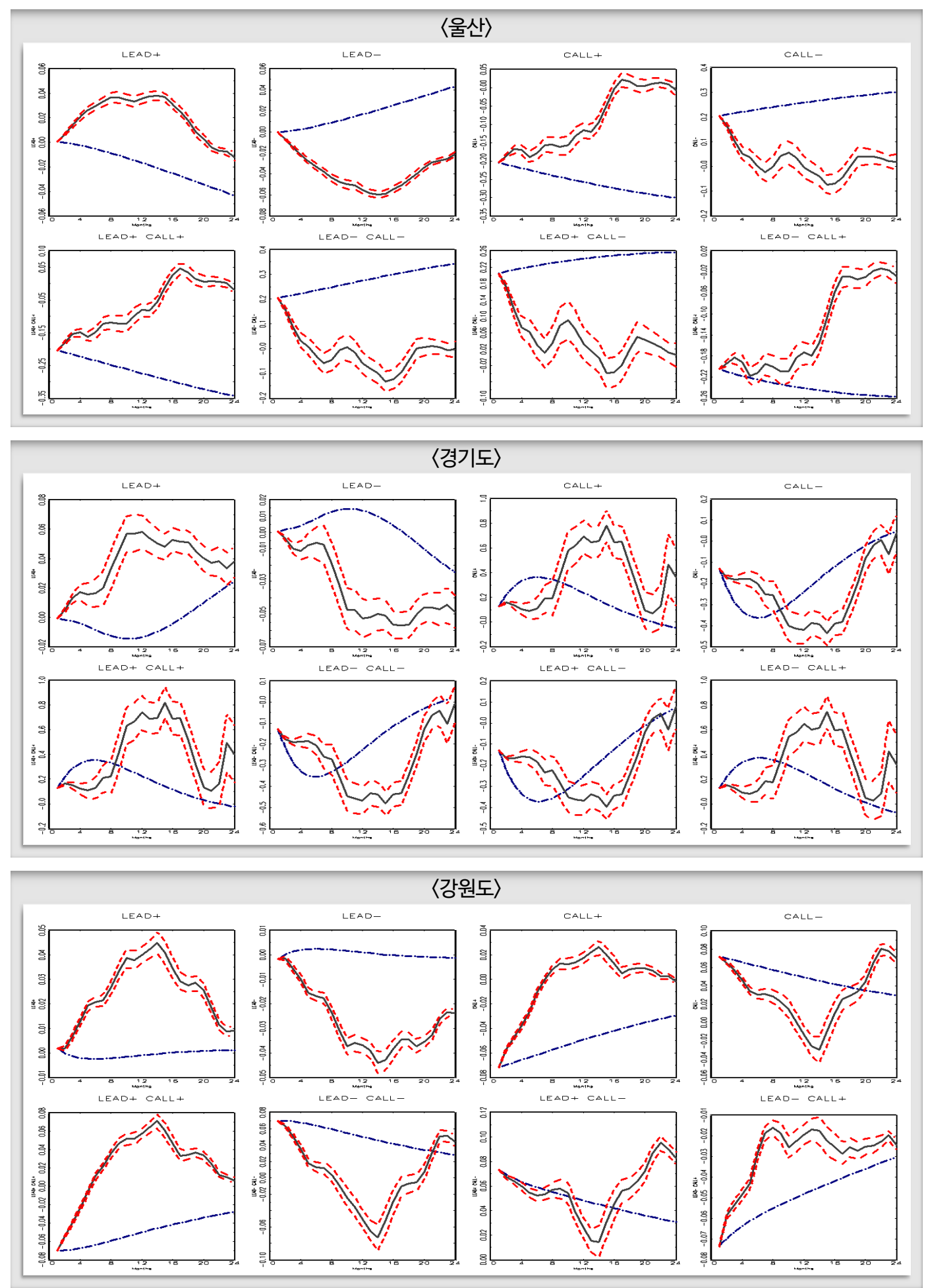

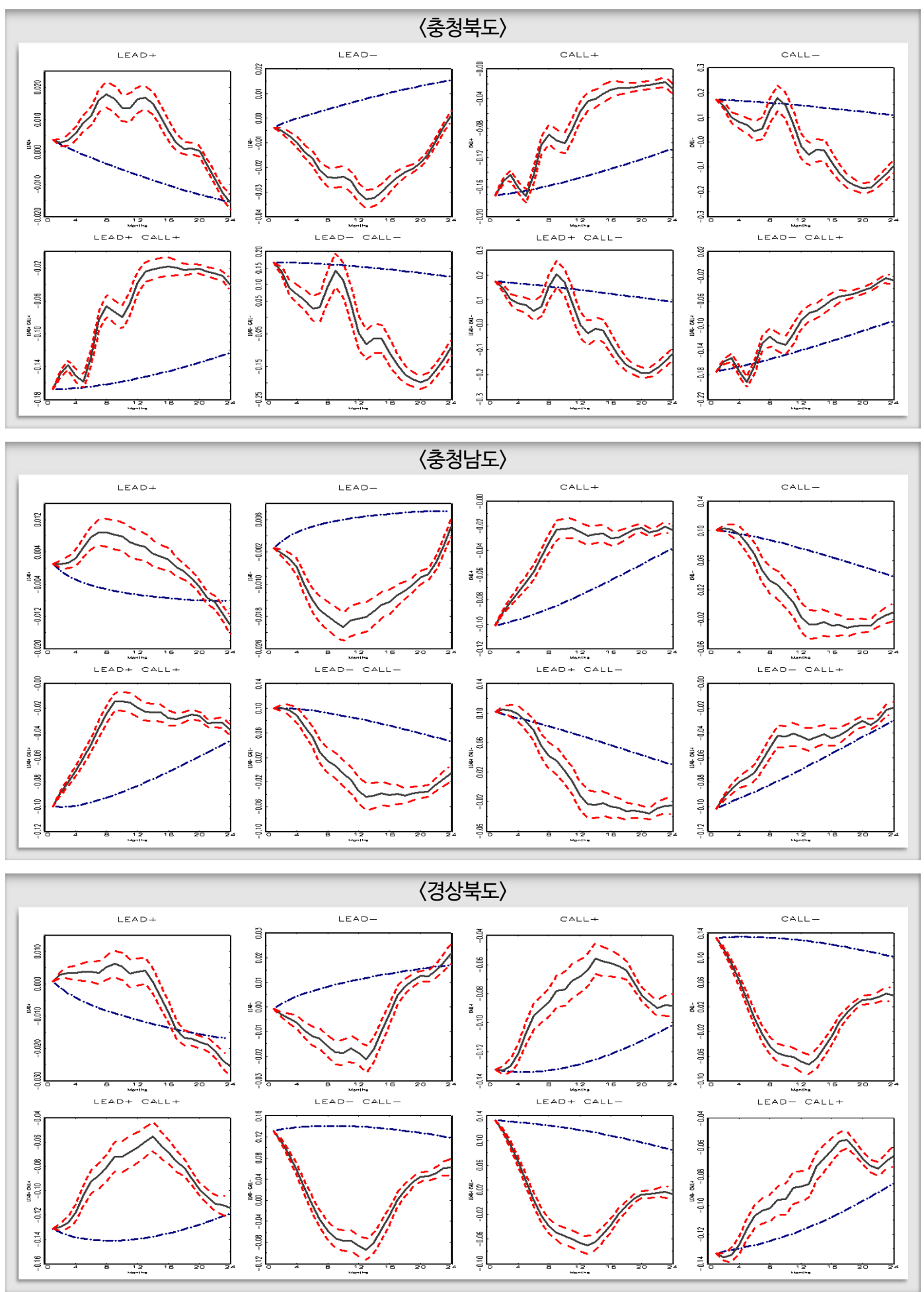
주택금융연구 VOL 3
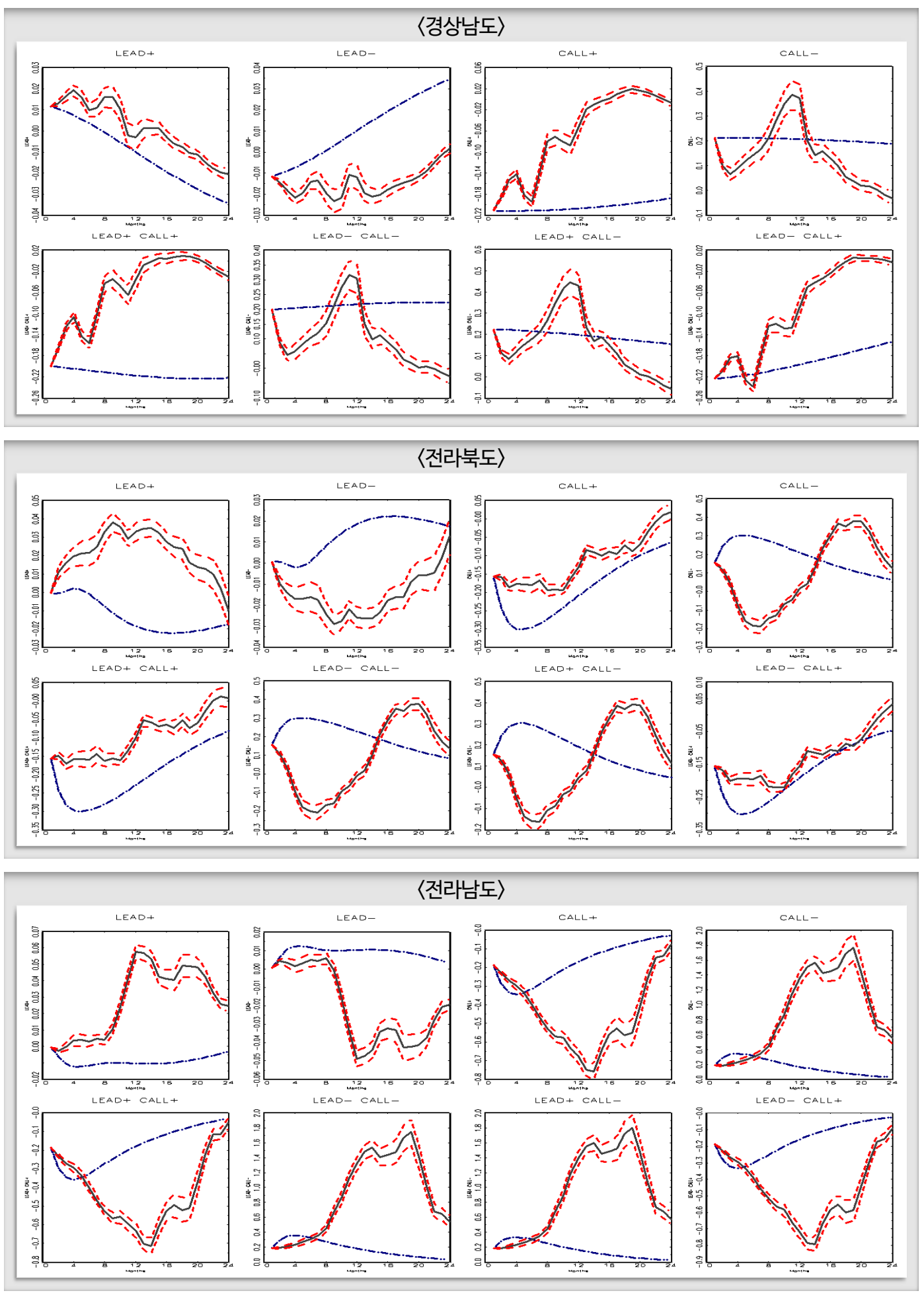